\title{
STANDARDIZED PRECIPITATION EVAPOTRANSPIRATION INDEX (SPEI) AS A TOOL TO DETERMINE THE HYDROLOGICAL DYNAMIC OF PLAIN REGIONS (ARGENTINA)
}

\author{
ÍNDICE PADRONIZADO DE PRECIPITAÇÃO E EVAPOTRANSPIRAÇÃO COMO UMA \\ FERRAMENTA PARA DETERMINAR A DINÂMICA HIDROLÓGICA DE REGIÕES PLANAS \\ (ARGENTINA)
}

\author{
Vanesa Yael BOHN ${ }^{(1,2,3)}$ \& María Cintia PICCOLO ${ }^{(1,3,4)}$ \\ ${ }^{1}$ Departamento de Geografía y Turismo, Universidad Nacional del Sur (UNS). 12 de octubre y San Juan, 4to. Piso, (8000) Bahía \\ Blanca, Buenos Aires, Argentina. Te.: 54 (291) 4595144. Email: vbohn@criba.edu.ar, ofpiccol@criba.edu.ar \\ ${ }^{2}$ Consejo de Investigaciones Científicas y Técnicas (CONICET) \\ ${ }^{3}$ Proyecto PAMPA 2 (Redes CONICET) \\ ${ }^{4}$ Instituto Argentino de Oceanografía (IADO-CONICET)

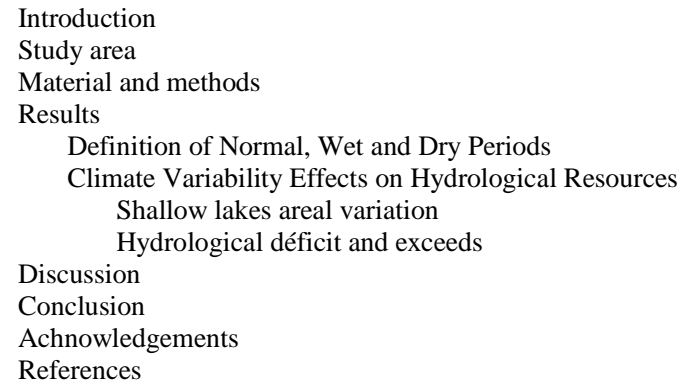

ABSTRACT - The Standardized Precipitation Evaporation Index (SPEI) in a 12 months' timescale was used to define wet, normal and dry cycles in four representative sites of climatic sub regions of the Central Plains of Argentina. The studied period was 19802016. Hydrological dynamic was defined by analysis of shallow lakes areal variations and hydrological deficits and exceeds calculation. Data ranges and frequency of data were statistically analyzed. Along the studied period, the frequency of normal and humid years was higher than the dry ones. Nineteen eighty-five, 2008 and 2009 were some dry years, defined by SPEI. Effectively, regarding hydrological dynamic, there was noted a decrease (from $0.9 \%$ to $96 \%$ ) of the shallow lakes areas during the aforementioned periods, in relation with their area during the humid ones. Hydrological deficit were noted during the 1995 and 2008 dry years in the site of the north and the rest of the sites, respectively. Also, exceeds amounts showed a response to the climatological cycles, during extremely wet years (i.e.: 1998 (NW of the studied area), 2001 (center), 2002 (NE) and 2009, in the northern site).

Palavras-chave: Normal, wet and dry years; Hydrological responses; SPEI.

RESUMO - Utilizou-se o Índice Padronizado de Precipitação e Evapotranspiração (em inglês, SPEI) numa escala de tempo de 12 meses para a definição dos ciclos úmidos, normais e secos em 4 zonas representativas das sub-regiões climáticas das Planícies Centrais da Argentina. O período de estudo foi 1980-2016. A dinâmica hidrológica foi definida através da análise de variações na extensão de lagoas e o cálculo dos déficits e excessos hídricos. Os intervalos e frequências de dados foram analisados estatisticamente. Durante todo o período de estudo, a frequência do ano normal e úmido foi maior do que os anos de seca. Os anos de 1985, 2008 e 2009 foram definidos como secos. De fato, em relação à dinâmica hidrológica, percebeu-se uma diminuição (de 0,9\% para 96\%) das áreas das lagoas durante o referido período, em relação a suas áreas durante os períodos úmidos. Os períodos de déficit hidrológico foram observados durante os anos de 1995 e 2008 na zona ao norte e em outras zonas, respectivamente. Além disso, os valores de quantias excessivas mostraram uma resposta a ciclos climáticos, durante anos extremamente úmidos (ou seja: 1998 (NO da área de estudo), 2001 (centro), 2002 (NE) e 2009, ao norte).

Palavras-chave: Anos normais, úmidos e secos; Respostas hidrológicas, SPEI.

\section{INTRODUCTION}

Climate variability, an important global environmental challenge, not only has a serious impact on the natural ecosystems, fresh water supply (Jeelani et al., 2008; Kingsford, 2011) but also have far reaching implications for societies in the 21st century (McElroy \& Baker, 2014). Numerous researches focused in the relation between climate variability, hydrological variables (physical and biological changes) and land use (De Sherbinin, 2014; Mushtaq \& Nee Lala, 2016; Bohn, et al., 2016). Droughts and floods are the world's most damaging and pressing natural disasters causing tens of billions of dollars in global damages (Wilhite, 2000), and collectively affecting more people than any other form of devastating climaterelated hazards.

Droughts and floods as well as dry and wet periods are complex natural hazards that are hard to identify, monitor and analyze. One of the causes could be associated with objectively quantifying their characteristics in terms of intensity, magnitude, duration and spatial extent. Consequently, determining drought mechanisms is problematic and it is very difficult to establish their extent and cessation. Moreover, drought is a 
multiscale phenomenon, which adds much complexity to any analysis. Many previous studies (Carbone \& Piccolo, 2002; Wu et al., 2011, Bohn et al., 2016) have evaluated the dryness or wetness variations over world using different drought indices. Natenzon \& Ríos (2011) indicated that floods and droughts are the most relevant features of social vulnerability in Argentina.

Vicente-Serrano et al. (2010) clearly illustrated these characteristics of droughts through consideration of usable water resources, including soil moisture, groundwater, snowpack, river discharges and reservoir storages. During floods and humid years, the time period from the arrival of water inputs to the availability of given usable water resource varies considerably (VicenteSerrano, 2007). Thus, the time scale over which water deficits accumulate becomes extremely important, and functionally separates hydrological, environmental, agricultural and other types of droughts.

The SPEI (Standardized Precipitation Evaporation Index) adapts the varied response times of hydrological variables to the climate variability (Vicente Serrano et al., 2010) and it facilitates identification of the complexity of the ecosystems response to various drought time scales (Vicente Serrano et al., 2012). A recent comparison (Vicente-Serrano et al., 2012) of the capacity of different climatological indices (SPI (Stardardized Precipitation Index) and SPEI) applied to identify hydrological, ecological and agricultural droughts at the global scale showed that, independently of the analyzed system, the drought indices calculated at different time scales (the SPEI and the SPI) show greater correlation with the temporal variability of streamflow, soil moisture, treering growth and crop production.

Regarding to the climatological index, the SPEI was applied for a temperate area of Argentina in conjunction with the oceanic Niño index (ONI) and in situ annual precipitation data to determine wet, dry and normal years (Bohn et al., 2016). Subsequently, those data related to dynamics of surface area (shallow lakes areal variation) and the variability of the land use intensity.

Frequency in the maximum of shallow lake areas was relatively more dependent on any changes in the rainfall regime (ENSO events) than in the land use (decrease/increase of the cultivated area). The El Niño (2002/3) and La Niña (2007/8) events clearly affected the precipitations of the total studied lake regions, with maximum areas in 2002 and minimum in 2008. The monitoring of the hydrological extremes has been improved by means the use of these indices and satellite data.

In this context, the focus is on the definition of wet and dry cycles and their effects on hydrological variables in representative sites of 4 climatological subregions of the Central Plains of Argentina. The goal was to provide some basic relation between climatological and hydrological variables for drought/floods disaster risk assessment.

\section{STUDY AREA}

Central Plains of Argentina include the Pampas and Espinal subregions (Diovisalvi et al., 2015), which cover a total extension of about $673,000 \mathrm{~km}^{2}$ (Viglizzo et al., 2011), and represent one of the largest wetland areas of South America (Quirós et al., 2002). This region is a heterogeneous environment, that includes the large Pampean plains, crossed by rivers and scattered with shallow lakes; extensive inland and marine dune systems; and mountain ranges, such as Tandilia and Ventania systems of the Buenos Aires Province (Figure 1) (Diovisalvi et al., 2015). Plains are exposed to permanent and cyclical floodings, and therefore numerous wetlands are frequent such as in the northeast of the region (Arturi, 2005; Viglizzo et al., 2011).

Regarding soils, the region is developed in the
Mollisol order USDA soil taxonomy (Pereyra, 2012). Mollisols formed in semi-arid to semihumid areas, typically under a grassland cover. The aptitude of soils for farm activities declines to the southwest, in concordance with the pluviometric regime.

The climate of the studied area is characterized as temperate with different subregions that oscillated between very humid to dry (Aliaga et al., 2016). The mean annual rainfall ranges from $1200 \mathrm{~mm} . \mathrm{yr}^{-1}$ to $400 \mathrm{~mm} \cdot \mathrm{yr}^{-1}$ in the southwest of the region. The mean annual temperature ranges from $22{ }^{\circ} \mathrm{C}$ to $14{ }^{\circ} \mathrm{C}$, from northeast to southwest of the Central Plains of Argentina (Arturi, 2005; Viglizzo et al., 2011). During the last 40 years, the anthropogenic action and the cultivated area significantly increase in the studied region. 


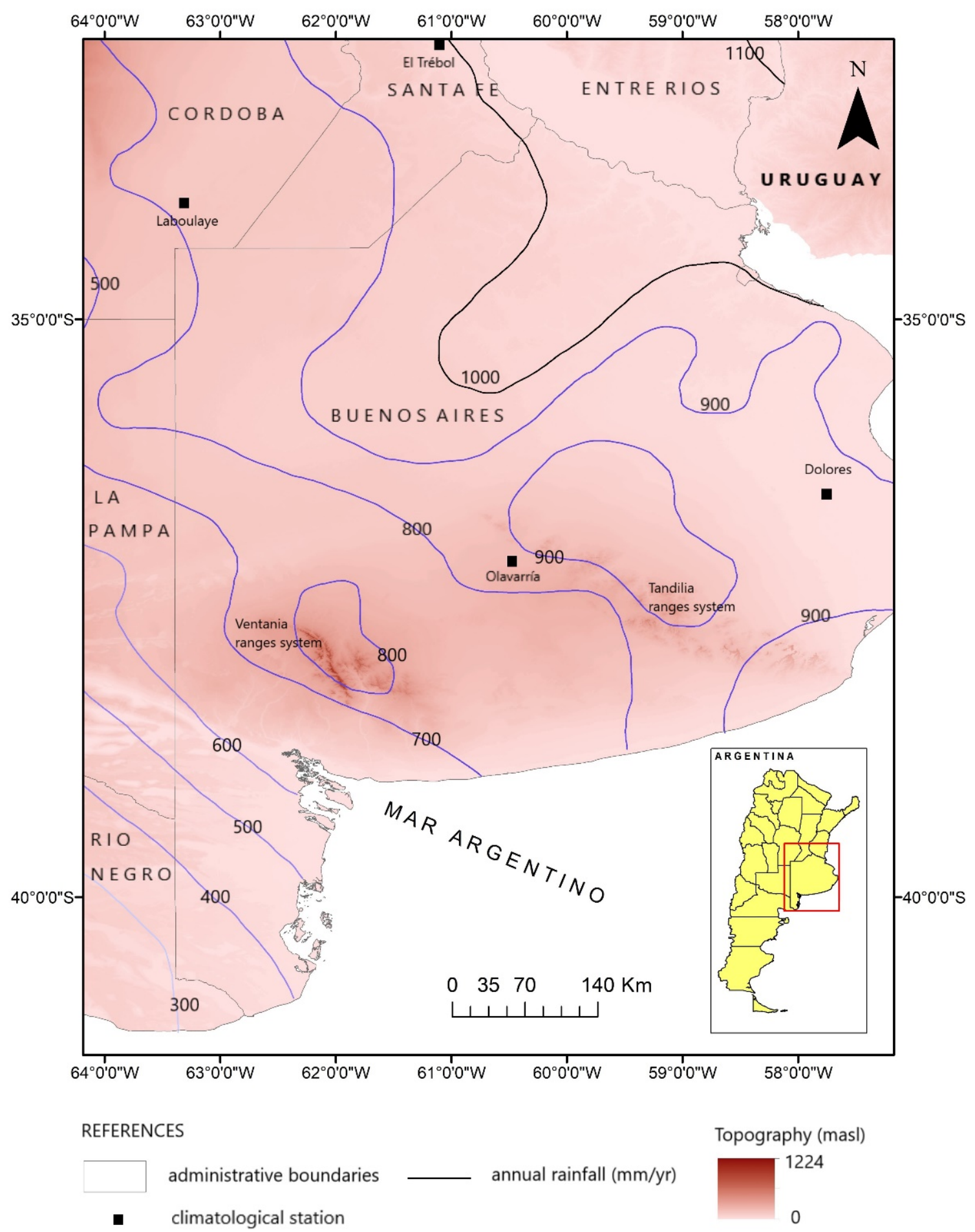

Figure 1 - Study area is located in the Central Plains of Argentina.

The study sites were chosen according to a recent climatological classification for the study area (Aliaga et al., 2016), which is based on the amount of rainfall. In this study, four sites are analyzed: Laboulaye, Olavarría, El Trébol and Chascomús (Figure 1, Table 2). Laboulaye belong to the "humid subregion", Olavarría is located in a transitional zone between the humid and moderately humid subregions whereas El Trébol and Chascomús are located in the "moderately humid subregion" (Aliaga et al., 2016). Regarding to soils of every studied site, the mollisol order is dominant (Panigatti, 2010). In the $\mathrm{N}$ of the study area (El Trébol site), soils show slow runoff, moderate permeability, topographic slope $<0.3 \%$ and therefore these soils present well drainage. The water table for this region is at depths ranging from 6 to $10 \mathrm{~m}$. Crops are the most expanded land use. In Laboulaye site (NW of the region), 
soils are associated to a topographic slope $<1$ $\%$, a slow and moderate runoff, a moderate permeability and the water table is deep. In Olavarría site, in the center of the area, soils are associated with the ranges of the Tandilia System (Figure 1). The topographic slope ranges between $1-3 \%$, the runoff and the permeability are moderate/fast. Finally, in the flat areas of the $E$ of the studied region (Chascomús site), soils show a slow runoff and permeability and a poor drainage. The topographic slope is between $0-0.4 \%$ and the water table is at depths of around $1.2 \mathrm{~m}$. The main limitation is the drainage.

\section{MATERIAL AND METHODS}

This research offers a study for 4 representative sites of the central plains in Argentina that combines the analysis of the climate variability and the fluctuation of some hydrological variables. As a novel method for this geographic area, the cycles have been defined by a climatological index in a 12months timescale (which is related to surface waters). Although there are investigations that define cycles in the studied region, they were based on rainfall amounts and soils humidity balances (Sierra et al., 1994; Serio et al., 2007; Scarpati \& Capriolo, 2013; Aliaga et al., 2016). The cycles defined in this research could be denominated as "hydrological cycles" due to the consequences of the climatological variability were manifested at surface waters and hydrological balances. This term also appears in recent studies in the Marcos Juárez region, in the $\mathrm{NW}$ of the central plains of Argentina (Andreucci et al., 2016).

In order to identify normal, wet and dry cycles the Standardized Precipitation Evapotranspiration Index (SPEI) was applied (Vicente-Serrano et al., 2010). The SPEI uses the monthly (or weekly) difference between precipitation and potential evapotranspiration and can monitor both dry and wet conditions. Negative and positive values indicate dry and wet periods, respectively (Tan et al., 2015) (Table 1).

It represents a simple climatic water balance that it is calculated at different scales of time to obtain the SPEI. The average value of SPEI is 0 , and the standard deviation is 1 . The SPEI is a standardized variable, and it can therefore be compared with other SPEI values over time and space (Vicente-Serrano et al., 2010). The SPEI data series were obtained, free of charge, with a 0.5 degrees spatial resolution and a monthly time resolution (CSIC, Consejo Superior de Investigaciones Científicas).

It has a multi-scale character, providing SPEI time-scales between 1 and 48 months. It is able to identify climate change processes related to changes in precipitation and/or temperature, and can be used to assess the possible influences of warming. The parameters of the SPEI are a time-series of total monthly precipitation $(\mathrm{P})$ and monthly potential evapotranspiration (PET). The details of the SPEI computation, more thoroughly, are described in Vicente-Serrano et al. (2010). The SPEI can be calculated at any timescale, but typically the 1, 3, 6, 12 and 24 months are used. Drought at these time scales is relevant for agriculture (1, 3, and 6month), hydrology (12 month) and socioeconomic impact (24 month). In addition, the 1 month SPEI reflects a short-term condition; the 3 month SPEI provides a seasonal estimation of precipitation; the 12 month SPEI also reflects medium-term trends in precipitation patterns and may provide an annual estimation of water condition. Data ranges, variation frequency of data were statistically analyzed by distribution fitting (5\% significance level, maximum likelihood estimation method).

Table 1 - SPEI classes (Vicente-Serrano et al., 2010).

\begin{tabular}{l|c}
\hline SPEI & Categories \\
\hline$>=2$ & Extremely wet \\
\hline $\mathbf{1 . 5}$ to 1.99 & Very wet \\
\hline $\mathbf{1}$ to 1.49 & Moderately wet \\
\hline $\mathbf{- 0 . 9 9}$ to 0.99 & Normal \\
\hline$-\mathbf{1}$ to -1.49 & Moderately dry \\
\hline $\mathbf{- 1 . 5}$ to -1.99 & Very dry \\
\hline$<=-2$ & Extremely dry \\
\hline
\end{tabular}

The analyzed hydrological variables were: shallow lakes areal variation and hydrological deficit and exceeds corresponding to the 4 representative sites of climatological subregions (Figure 1, Table 2). The shallow lakes areal variation was analyzed from satellite image processing.

Landsat Surface Reflectance satellite products were provided, free of charge, by United States Geological Survey (USGS). They were processed during selected periods, representative of 
extremes cycles, based on the previous climatological indices analysis. Eight shallow lakes areas were obtained by segmentation image of the band 4 of Landsat satellite image, for previously defined humid and dry cycles. Monitored shallow lakes (Table 2), for each
Landsat scene, were randomly selected. Servicio Meteorológico Nacional (SMN) provided climatological data series (monthly rainfall and temperature). Hydrological deficit and exceeds were quantified by hydrological balance calculation (Thorntwaite, 1948).

\section{RESULTS}

\section{Definition of Normal, Wet and Dry Periods}

According SPEI (at 12 month timescale), different climatological cycles were identified, for every station (Figure 1, Table 2).

As a result, 5 humid periods and 4 dry periods were found in Chascomús (meteorological station: Dolores) region, of the NE of the Central Plains of Argentina (Figure 1). Regarding to humid periods, the longest one was identified between January 2001 and February 2003, although it showed an alternance with "normal" months. According to the temporal duration there were cited as humid periods August 1980 to March 1981, January to December 1989, April 1993 to October 1994 and June 2014 to February 2015 as humid periods (Figure 2a).

On the other hand, there could be distinguished as the longest dry period the time between April 2011 and July 2012, whereas shorter dry periods comprise January to March 1980, April to August 1996 and November 2008 to November 2009 (Figure 2a).

The highest and lowest value for SPEI index were found during January 2001 to February 2003 (SPEI= 2.38) and during November 2008 to November 2009 (SPEI= -2.33), respectively. Concerning Olavarría region, 5 humid events were determined, being August 2001 to April 2003 and February 1992 to January 1993 the longest and strongest periods (Figure 2b). The longest dry periods for this area were December 2007 to January 2010 and June 1994 to May 1996. During the first of these periods the SPEI surpassed the value of 3 , being an extremely dry condition.

In El Trébol region 7 and 6 humid and dry periods were defined, respectively. December 1995 - December 1997 was distinguished as the longest dry period whereas the November 1990 - March 1992 was distinguished as the longest humid period (Figure 2c).

The extreme values of SPEI were found during shorter periods: SPEI $=2.02$ during January 2010 - November 2010 and SPEI= -
2.41 during March 2008-August 2009. Finally, in the NW of the study area (Laboulaye site), there were noted 7 humid and 3 dry periods.

The November 1992 - September 1994 was characterized as the longest humid period whereas the same condition was for March 2008-November 2009 period in the category of dry cycles (Figure 2d). November 1990-April 1992 was a short humid period but the strongest. During the aforementioned period SPEI index reached the 1.87 value. The lowest SPEI values (SPEI $\sim-2$ ) occurred during January-December 1989.

Normal periods were the most frequent category in the 4 analyzed sites and for the 12 month timescale of SPEI index. Moderately humid periods were predominant (after the normal category) in Chascomús (meteorological station: Dolores) (12\%) and Laboulaye (12\%) areas whereas the moderately dry cycles were more usual in El Trébol (11.16\%) and Olavarría (12.07 \%) regions, for a 12 month timescale (Figure 3).

\section{Climate Variability Effects on Hydrological Resources \\ Shallow lakes areal variation}

Eigth shallow lakes were monitored by satellite image processing, during previously selected dry and humid periods (Table 2). They were randomly selected in relation with studied station, in the NE, NW, center and $\mathrm{N}$ of the central plains of Argentina (Figure 1, Table 2). In all cases, during the dry period, the shallow lake area diminished (since $96 \%$ to $0.9 \%$ ). Moreover, in a case located in Laboulaye zone, during the dry period, the shallow lake was extinguished (Figure 4). On the contrary, during a humid period, the shallow lake located near to El Trébol station was incorporated into a river flow (Figure 4).

\section{Hydrological deficit and exceeds}

Twelve hydrological balances were calculated, for every region, in order to estimate hydrological excess and deficits. 

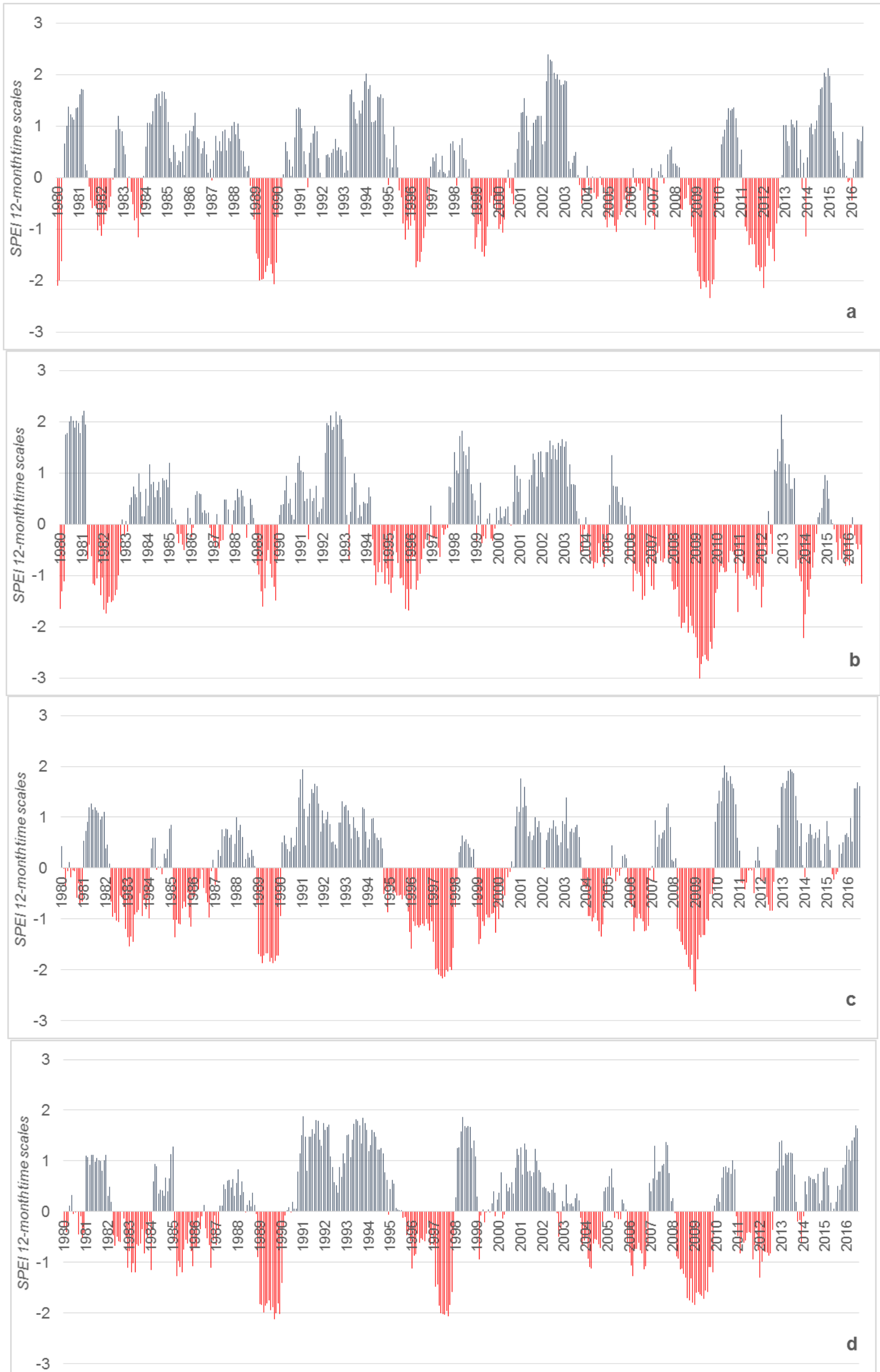

Figure 2 - SPEI 12-months timescales applied to stations for determination of dry and wet periods, in the study area (1980-2016): a) Chascomús (climatological station: Dolores); b) Laboulaye; c) El Trébol; d) Olavarría. 


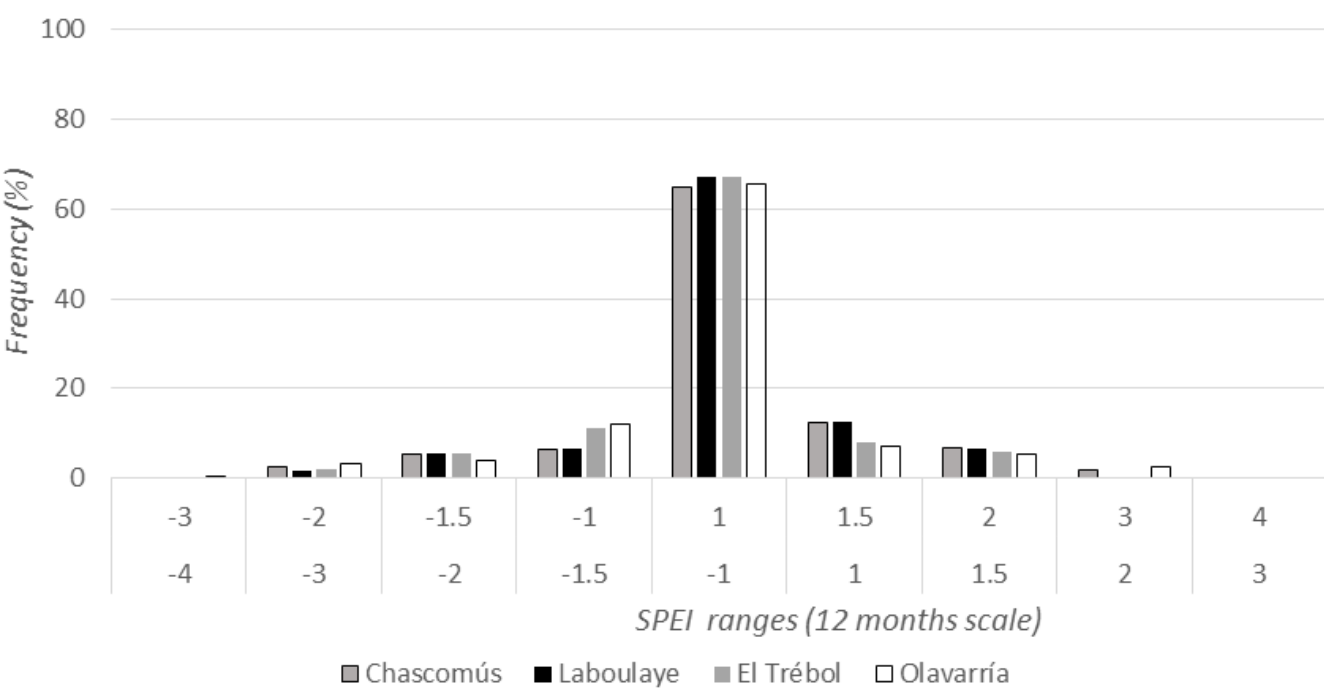

Figure 3 - Frequency analysis of SPEI (12 months scale) in the 4 sites, by SPEI ranges (Table 1), during the studied period (1980-2016)

Table 2 - Location of the randomly shallow lakes selected, monitored during dry and humid periods.

\begin{tabular}{|c|c|c|c|c|c|c|}
\hline $\begin{array}{c}\text { Shallow } \\
\text { lake }\end{array}$ & $\begin{array}{c}\text { Landsat } \\
\text { scene } \\
\text { (path/row) } \\
\end{array}$ & $\begin{array}{c}\text { Location (South } \\
\text { Latitude/ West } \\
\text { Longitude) } \\
\end{array}$ & $\begin{array}{c}\text { Date } \\
\text { (Dry } \\
\text { period) }\end{array}$ & $\begin{array}{c}\text { Date } \\
\text { (humid } \\
\text { period) }\end{array}$ & $\begin{array}{c}\text { Climatological } \\
\text { station }\end{array}$ & SPEI Grid \\
\hline 1 & \multirow{3}{*}{ 226/086 } & $38^{\circ} 3^{\prime} 49^{\prime \prime} / 62^{\circ} 24^{\prime} 19^{\prime \prime}$ & 2009 & 2001 & Olavarría & $36^{\circ} 47^{\prime} 45^{\prime \prime}$ \\
\hline 2 & & $38^{\circ} 0^{\prime} 50^{\prime \prime} / 62^{\circ} 22^{\prime} 6^{\prime \prime}$ & 2009 & 2001 & & $60^{\circ} 14^{\prime} 7^{\prime \prime}$ \\
\hline 3 & & $38^{\circ} 20^{\prime} 52^{\prime \prime} / 60^{\circ} 26^{\prime} 48^{\prime \prime}$ & 2009 & 2001 & & \\
\hline 4 & \multirow{3}{*}{$224 / 085$} & $35^{\circ} 47^{\prime} 46^{\prime \prime} / 58^{\circ} 13^{\prime} 17^{\prime \prime}$ & 2009 & 1990 & Chascomús & $35^{\circ} 34^{\prime} 51^{\prime \prime}$ \\
\hline 5 & & $36^{\circ} 5^{\prime} 1^{\prime \prime} / 58^{\circ} 1^{\prime} 6^{\prime \prime}$ & 2009 & 1990 & & $58^{\circ} 00^{\prime} 49^{\prime \prime}$ \\
\hline 6 & & $36^{\circ} 7^{\prime} 15^{\prime \prime} / 57^{\circ} 59^{\prime} 30^{\prime \prime}$ & 2009 & 1990 & & \\
\hline 7 & \multirow{2}{*}{ 228/084 } & $35^{\circ} 15^{\prime} 7^{\prime \prime} / 63^{\circ} 20^{\prime} 59^{\prime \prime}$ & 2009 & 1986 & Laboulaye & $34^{\circ} 15^{\prime} 31^{\prime \prime} / 63^{\circ} 14^{\prime} 30^{\prime \prime}$ \\
\hline 8 & & $35^{\circ} 19^{\prime} 0^{\prime \prime} / 63^{\circ} 20^{\prime} 2^{\prime \prime}$ & 2009 & 1986 & El Trébol & $32^{\circ} 12^{\prime} 47^{\prime \prime} / 61^{\circ} 42^{\prime} 46^{\prime \prime}$ \\
\hline
\end{tabular}

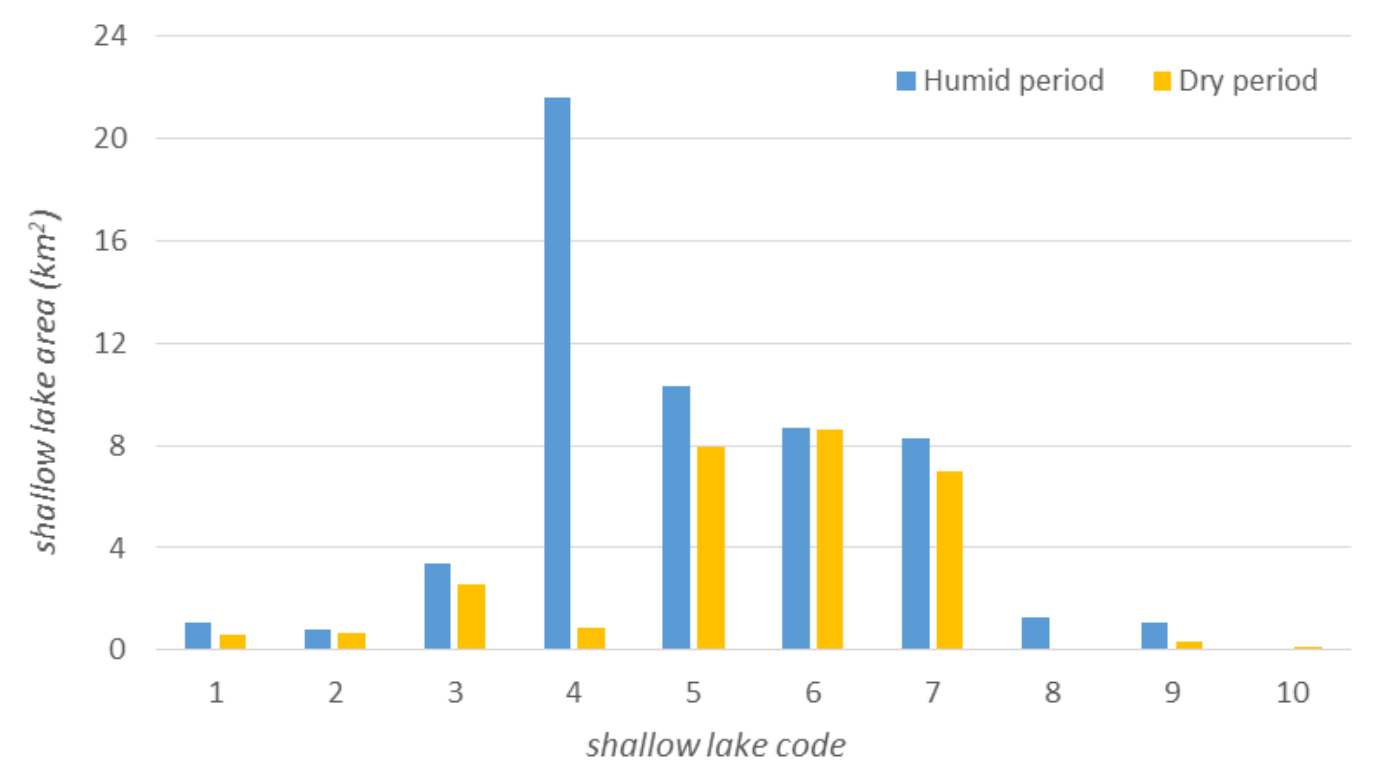

Figure 4 - Shallow lakes areal variation during humid and dry cycles, in eight randomized selected shallow lakes.

The hydrological balance were done for a normal, dry and humid periods, for every studied site. Regarding the normal balance, they included the $\sim 30$ year average of a weather variable (Table 3) data. Hydrological balances corresponding to dry and humid years were done according to the previous SPEI categorization (Table 3). 
Table 3 - Periods and years of data analyzed for the hydrological balance calculation.

\begin{tabular}{l|c|c|c}
\hline \multirow{2}{*}{$\begin{array}{l}\text { Climatological } \\
\text { station }\end{array}$} & \multicolumn{3}{|c}{ Analyzed period/years } \\
\cline { 2 - 4 } & dry & Humid & $\begin{array}{c}\text { Normal } \\
\text { (annual precipitation) }\end{array}$ \\
\hline El Trébol & 1995 & 2009 & $1990-2016(1017 \mathrm{~mm})$ \\
\hline Dolores & 2008 & 2002 & $1950-2016(935 \mathrm{~mm})$ \\
\hline Laboulaye & 2008 & 1998 & $1956-2016(867 \mathrm{~mm})$ \\
\hline Olavarría & 2008 & 2001 & $1988-2016(908 \mathrm{~mm})$ \\
\hline
\end{tabular}

As a result, there was a direct relationship between the hydrological surplus and deficits and the years defined as humid and as dry by SPEI analysis, respectively. Regarding the hydrological deficit, it was higher during the dry periods, for all analyzed stations, than the normal period (Figure 5). The highest increase of this variable was found in El Trébol and
Dolores stations ( 55 and $52 \%$, respectively), during the dry selected years. According to the excess, there was denoted an increase for all analyzed cases.

The maximum increase (in relation with the excess of a climatological normal value) was found in Laboulaye station ( $92 \%$ ), during the humid period (Figure 6).

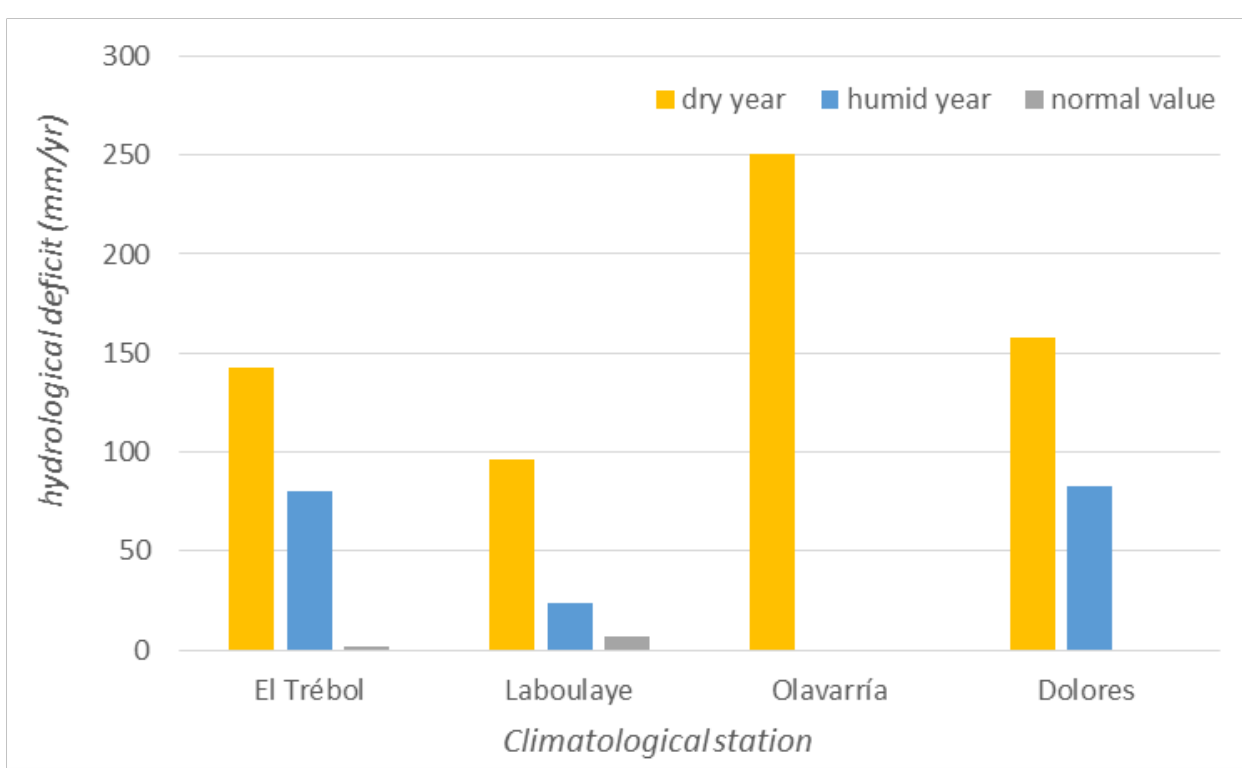

Figure 5 - Hydrological deficit $\left(\mathrm{mm}_{\mathrm{yr}} \mathrm{y}^{-1}\right)$ in every climatological station during dry and wet years and during a normal climate period.

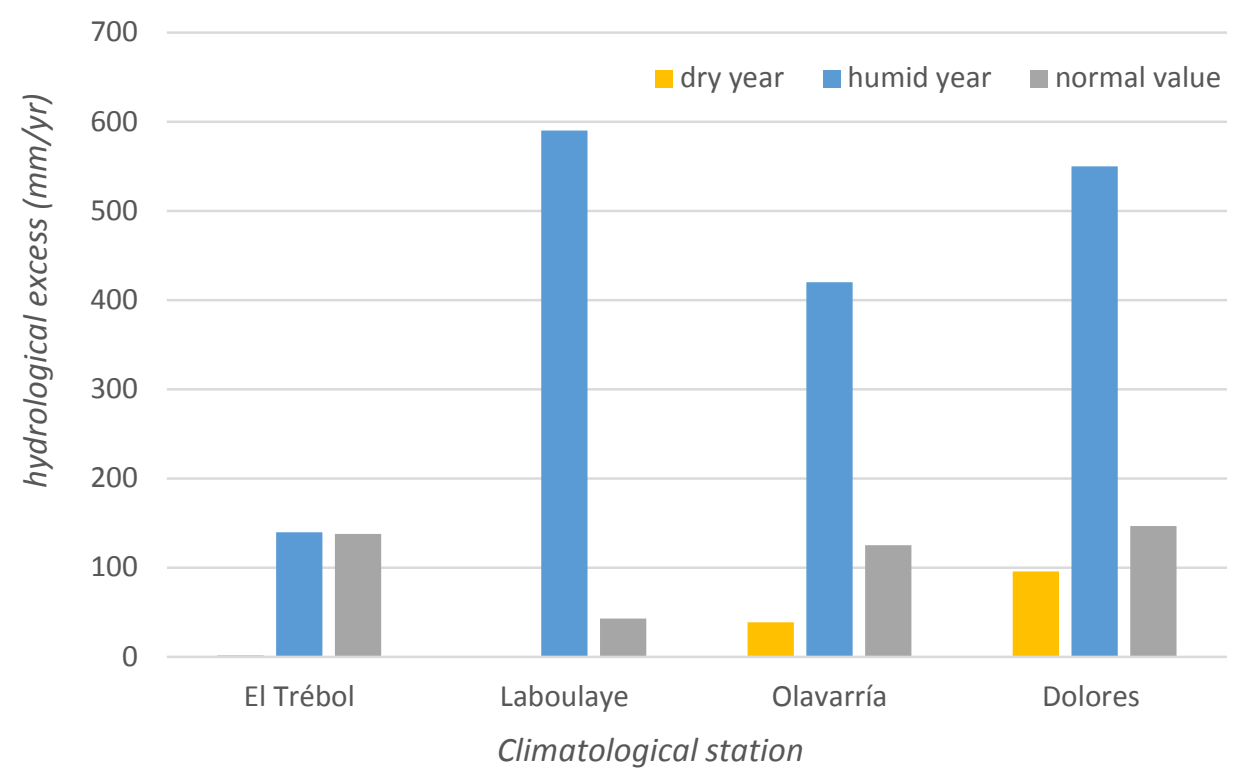

Figure 6 - Hydrological excess (mm.yr ${ }^{-1}$ ) in every climatological station during dry and wet years and during a normal climate period. 


\section{DISCUSSION}

The results revealed that the SPEI is an appropriate indicator of hydrological fluctuations in the study area due to the possibility to apply it in different timescales. Numerous scientific studies have shown that particular systems and regions can respond to drought conditions at very different time scales. In terms of water resources, Vicente-Serrano \& López-Moreno (2005) showed that the response of river discharges and reservoir storages to different drought time scales in mountainous catchments may be diverse (1-2 months for river discharges and 8-10 for reservoir storages). Szalai et al. (2000) also showed that water stored in reservoirs in Hungary responded to longer time scales (5 to 24 months) than streamflows (2 to 6 months). Large differences were also observed using groundwater data (e.g., Khan et al., 2008; Fiorillo \& Guadagno, 2010). A similar fact could be observed for other systems, such as crops or natural vegetation.

The effects of the climate variability on the hydrology are conditioned by numerous variables such as land use, land cover and others (Kaser et al., 2010; Insaf et al., 2013; Liu et al., 2016). This work did not include the totality of these variables. However, there could be shown the influence of climatological variability in some hydrological components of the system. The results presented here, are comparable to the findings of Aragón et al.
(2011) in relation with the coverage water and climatological events correlation, for the NW of the Central Plains of Argentina.

The SPEI is the most commonly used index in order to define wet, dry and normal years and to monitor droughts (Botai et al., 2016). In this research, the climatological index was used in relation with hydrological measurements. SPEI incorporates, as a difference from SPI (Mc Kee et al., 1995), the temperature data. This feature appeared as an advantage in relation of the SPEI cycles definition and the hydrological balances (deficits and surplus amounts). Regarding SPEI vs. shallow lakes areal variation, the relation between climate parameters and surface water dynamics was lineal, which is comparable with other studies (Herrera-Pantoja et al., 2008; Mahmood et al., 2016).

Regarding floods, plains areas are the most vulnerable landscape in the world. However, the hydrological research in the aforementioned geomorphic unit, are scarce (Usunoff et al., 2000). Studies like this provide tools for management and prevention of risks. The availability of SPEI data (Vicente-Serrano et al., 2010) (in a large spatial and temporal scale) as well as the correlations found in this research, gives the possibility to extrapolate them. The extrapolation could be in other similar areas or in the same area, in the past and in a future time by prediction methods.

\section{CONCLUSION}

By SPEI application (12 months timescale) for the central plains in Argentina, during the 1980-2016 years, there was possible to define climatological cycles. The cycle definition by SPEI data series analysis, in four sites located in the studied area was done. As a result of the regional analysis, there were distinguished 6 cycles, which occurred simultaneously in the four sites analyzed (representatives of the continental, temperate and very humid, temperate oceanic and temperate highland of Ventania hills climatological subregions). Four of them were dry: 1989-1990; 1996-1997; 2008-2009 and 2011-2012 whereas 1990-1995 and 2001-2003 years were wet periods. The analysis of the climatological index showed a frequency of $60 \%$ for the occurrence of normal periods (in the 4 stations) and a $10-15 \%$ for the occurrence of moderately wet and dry periods.

Shallow lakes areal variation in contrast to the extreme climatological events showed a positive relation: the biggest and the smallest areas were found during wet and dry periods, respectively. The more distinguished case was the example number 8 (Esquivel shallow lake) which areal variation was of $\sim 96 \%$. It is located in the $\mathrm{E}$ of the studied area.

Also, there was found a lineal relationship between hydrological surpluss/deficits and extreme climatological events. Regarding the hydrological deficit, it was highest during the dry periods and for the four studied sites. The highest difference occurred in El Trébol station 
( $55 \%$ ). In all analyzed cases, hydrological positives and wet years, were correlated. Laboulaye station showed an increase of $92 \%$ between surplus belonging to a wet year and the surplus in normal conditions.

The SPEI was an appropriate indicator of the hydrological surplus and deficit and shallow lakes areal variations in central plains of Argentina. The climatological index indicated the effects of extreme events on the hydrology of the studied area. Also, by SPEI, there was possible to determine the frequency of every category of climatological events. This aspect is became relevant in order to assess about risks. Finally, the large spatial and temporal availability of the SPEI data series, in different timescales, is an important possibility for the estimation of hydrological fluctuations in similar geographic areas.

\section{ACKNOWLEDGEMENTS}

The authors thank INTA, United States Geological Survey (USGS), Servicio Meteorológico Nacional (SMN), Global SPEI Database and CSIC, Departamento de Geografía y Turismo (UNS). Financial supported by Proyecto Argentino de Monitoreo y Prospección de Ambientes Acuáticos (PAMPA2-CONICET), Universidad Nacional del Sur (UNS) and Consejo Nacional de Investigaciones Científicas y Técnicas (CONICET).

\section{REFERENCES}

ALIAGA, V.S.; FERRELLI, F.; ALBERDI ALGAÑARAZ, E.D.; BOHN, V.Y.; PICCOLO, M.C. Distribución y variabilidad de la precipitación en la Región Pampeana, Argentina. Cuadernos de Investigación Geográfica, v. 42, n. 1, p. 261-280, 2016.

ANDREUCCI, A.; CONDE, M.B.; BOLLATTI, P. Análisis del régimen de precipitaciones y nivel freático en la EEA INTA Marcos Juárez. Período 1948-2015. INTA Ediciones. Colección Divulgación nro. 18., 16p., 2016.

ARAGÓN, E.; JOBBÁGY, E.G.; VIGLIZZO, E.F. Surface and groundwater dynamics in the sedimentary plains of the western Pampas (Argentina). Ecohydrology, v. 4, n. 3, p. 433 - 447, 2011.

ARTURI, M. Situación ambiental en la ecorregión espinal. In: BROWN, A., MARTINEZ ORTIZ, U., ACERBI, M. \& CORCUERA, J. (Editors), La Situación Ambiental Argentina 2005, Fundación Vida Silvestre Argentina, Buenos Aires, 587p., 2006.

BOHN, V.Y.; DELGADO, A.L.; PICCOLO, M.C.; PERILLO, G.M.E. Assessment of climate variability and land use effect on shallow lakes in temperate plains of Argentina. Environ Earth Sci, v.75, n. 9, p. 818-833, 2016.

BOTAI, CH.; BOTAI, O.; DLAMINI, L.; PLADULI, E. Characteristics of Droughts in South Africa: A Case Study of Free State and North West Provinces. Water, v. 8, n. 10, p. 439-462, 2016.

DE SHERBININ, A. Mapping the Unmeasurable? Spatial Analysis of Vulnerability to Climate Change and Climate Variability, University of Twente. ITC, 234p., 2014.

DIOVISALVI, N.; BOHN, V.Y.; PICCOLO, M.C.; PERILLO, G.M.E.; BAIGÚN, C.; ZAGARESE, H.E. Shallow lakes from the Central Plains of Argentina: an overview and worldwide comparative analysis of their basic limnological features. Hydrobiologia, v. 752, p. 5-20, 2015.

CARBONE, E. \& PICCOLO, M.C. Caracterización de Las Sequías en la Localidad de Tres Arroyos. Papeles de Geografía. v. 36; p. 209-222, 2002.

FIORILLO, F. \& GUADAGNO, F.M. Karst spring discharges analysis in relation to drought periods, using the SPI. Water Resources Management, v. 24, p. 1867-1884, 2010.

HERRERA-PANTOJA, M. \& HISCOCK, K.M. The effects of climate change on potential groundwater recharge in Great Britain. Hydrological Processes, v. 22, n. 1, p. 73-86, 2008.

INSAF, T.Z.; LIN, S.; SHERIDAN, S.C. Climate trends in indices for temperature and precipitation across New York State, 19482008. Air Qual Atmos Health, v. 6, p. 247-257, 2013.
JEELANI, M.; KAUR, H.; KUMAR, R. Impact of Climate Warming on the Biodiversity of Freshwater Ecosystem of Kashmir, India. In: SENGUPTA, M. \& DALWANI, R. (Eds.), Proceedings of Taal 2007: The 12 World Lake Conference, p. 1103-1109, 2008.

KASER, G.; GROßHAUSER, M.; MARZEION, B. Contribution potential of glaciers to water availability in different climate regimes. Proc Natl Acad Sci. v. 107, p. 20223-20227, 2010.

KHAN, S.; GABRIEL, H.F.; RANA, T. Standard precipitation index to track drought and assess impact of rainfall on water tables in irrigation areas. Irrig. Drain. Syst., v. 22, p. 159-177, 2008.

KINGSFORD, R.T. Conservation management of rivers and wetlands under climate change a synthesis. Mar Freshwater Res., v. 62, p. 217-222, 2011.

LIU, Q.; YANG, Z.; HAN, F.; WANG, Z.; WANG, C. NDVIbased vegetation dynamics and their response to recent climate change: a case study in the Tianshan Mountains, China. Environ Earth Sci, v. 75, p. 1189, 2016.

MAHMOOD, T.H.; POMEROY, J.W.; WHEATER, H.S.; BAULCH, H.M. Hydrological responses to climatic variability in a cold agricultural region. Hydrological Processes, p. 1-17, 2016.

MCELROY, M.B. \& BAKER, D.J. Climate extremes: recent trends with implications for national security. Vermont $\mathbf{J}$. Environ. Law, v. 15, p. 727-803, 2014.

MCKEE, T.B.; DOESKEN, N.J.; KLEIST, J. Drought monitoring with multiple time scales. In: Proceedings of Ninth Conference on Applied Climatology, Dallas, TX, USA. Proceedings... Dallas, 1995, p. 233-236.

MUSHTAQ, F. \& NEE LALA, M.G.N. Remote estimation of water quality parameters of Himalayan Lake (Kashmir) using Landsat 8 OLI imagery. Geocarto Int., 2017.

NATENZON, C.E. \& RÍOS, D. (Eds.). Riesgos catástrofes y vulnerabilidades. Aportes desde la geografía y otras ciencias sociales para casos argentinos, 200p., 2015.

PANIGATTI, J.L. Argentina 200 años, 200 suelos. Ed. INTA Buenos Aires, p. 345, 2010.

PEREYRA, F. Suelos de la Argentina: geografía de suelos, factores y procesos formadores, SEGEMAR, p. 178, 2012.

QUIRÓS, R.; RENNELLA, A.M.; BOVERI, M.B.; ROSSO, J.J.; SOSNOVSKY, A. Factores que afectan la estructura y el funcionamiento de las lagunas pampeanas. Ecología Austral, v. 12, p.175-185, 2002.

SCARPATI, O.E. \& CAPRIOLO, A.D. Sequías e inundaciones 
en la provincia de Buenos Aires (Argentina) y su distribución espacio-temporal. Investigaciones Geográficas, Investigaciones Geográficas, v. 82, p. 38-51, 2013.

SERIO, L.; MURPHY, G.; HURTADO, R.; SPESCHA, L. El Índice Estandarizado de Precipitación y las Lluvias de Verano en la Región Pampeana. In: I Congreso Venezolano de Agrometeorología y V Reunión Latinoamericana de Agrometeorología, Maracay, 2007.

SIERRA, E.M.; HURTADO, R.H.; SPECHA, L. Corrimiento de las isoyetas anuales medias decenales en la región pampeana 1941-1990. Revista de la Facultad de Agronomía, v. 14, 2, p. 139-144, 1994.

SZALAI, S.; SZINELL, C.S.; ZOBOKI, J. Drought monitoring in Hungary. In: Wilhite, D.A., Sivakumar, M.V.K. \& Wood, D.A. Early Warming Systems for Drought Preparedness and Drought management. World Meteorological Organization, Lisboa, p. 182-199, 2000.

TAAL2007: The 12th World Lake Conference, Department of Zoology, Punjabi University Patiala, 2008, p. 1103-1109.

TAN, CH.; YANG, J.; LI, M. Temporal-Spatial Variation of Drought Indicated by SPI and SPEI in Ningxia Hui Autonomous Region, China. Atmosphere, v. 6, 1399-1421, 2015.

THORNTHWAITE, C.W. An Approach toward a Rational Classification of Climate. Geographical Review, v. 38, 1, p. 55-94, 1948.

USUNOFF, E.; VARNI, M.; RIVAS, R.E.; WEINZETTEL, P.A. Aspectos hidrogeológicos de relevancia de la llanura pampeana en el centro de la provincia de Buenos Aires, Argentina. In: Joint World Congress on Groundwater, I, 2000.

VICENTE-SERRANO, S.M. \& LOPEZ-MORENO, J.I. Hydrological response to different time scales of climatological drought: An evaluation of the standardized precipitation index in a mountainous Mediterranean basin. Hydrol. Earth Syst. Sci., v.9, p. 523-533, 2005.
VICENTE-SERRANO, S.M. Evaluating the Impact of Drought Using Remote Sensing in a Mediterranean, Semi-arid Region. Nat. Hazards, v. 40, p. 173-208, 2007.

VICENTE-SERRANO, S.M.; BEGUERIA, S.; LOPEZMORENO, J.I. A Multiscalar Drought Index Sensitive to Global Warming: The Standardized Precipitation Evapotranspiration Index. Journal of Climate, v. 23, p. 1696-1718, 2010.

VICENTE-SERRANO, S.M.; BEGUEREA, S.; LORENZOLACRUZ, J.; CAMARERO, J.J.; LOPEZ-MORENO, J.I.; AZORIN-MOLINA, C.; REVUELTO, J.; MORONTEJEDA, E.; SANCHEZ-LORENZO, A. Performance of drought indices for ecological, agricultural and hydrological applications. Earth Interact, v. 16, n. 1, p. 1-27, 2012.

VIGLIZZO, E.F.; FRANK, F.C.; CARREÑO, L.V.; JOBBAGY, E.G.; PEREYRA, H.; CLATT, J., PINCEN, D. \& RICARD, M.F. Ecological and environmental footprint of 50 years of agricultural expansion in Argentina. Global Change Biology, v.17, p. 959-973, 2011.

WILHITE, D. Drought as a natural hazard: concepts and definitions. In Drought: A Global Assessment, WHILHITE D (ed). Routledge: London; p. 3-18, 2000.

WILHITE, D. Drought as a natural hazard: concepts and definitions. In Drought: A Global Assessment, WHILHITE, D. (ed). Routledge:London; p. 3-18, 2000.

WU, Z.; LU, G.; WEN, L.; LIN, C. 2011. Reconstructing and analyzingChina's fifty-nine year (1951-2009) drought history using hydrological model simulation. Hydrology and Earth System Sciences, v. 15, p. 2881-2894, 2011. DOI: 10.5194/hess-15-2881 